Bangladesh J. Bot. 39(1): 37-46, 2010 (June)

\title{
POLLEN MORPHOLOGY OF SOME ALLIUM L. (LILLIACEAE) TAXA IN TURKEY
}

\author{
H. ÖZleR* and S. Pehlivan ${ }^{1}$ \\ Forest Tree Seeds and Tree Breeding Research Directorate, P.O. Box.11, Ankara-06560, Turkey
}

Key words: Allium, Codonoprasum, Rhizirideum, Alliaceae, Pollen morphology, Turkey

\begin{abstract}
Pollen grains of 16 taxa of Allium L. belonging to sections Rhizirideum G. Don ex Koch., Codonoprasum Reichb. and Allium L. were investigated using light and scanning electron microscope, and pollens of four taxa were also examined with transmission electron microscope. Pollens were monosulcate and ellipsoidal. It was observed that the sulcus extends from distal to proximal in all taxa. The exine was semitectate and the tectum was perforate. Columellae were simplicolumellate. Exine sculpture was striateperforate, striate-rugulate-perforate and rugulate-perforate. A. albidum Fischer ex Bieb. subsp. caucasicum (Regel) Stearn, A. rupicola Boiss ex Mouterde and A. asperiflorum Miscz. were seen to have an operculum.
\end{abstract}

\section{Introduction}

Allium L. (Lilliaceae) is represented by nearly 174 taxa in Turkey, under 14 sections (Davis $e t$ al. 1984, 1988, Seçmen et al. 1998, Güner et al. 2000). The taxa give the characteristic onion and garlic smell and also include species that are of medicinal and economic importance.

The members of the genus Allium present in Turkey are polymorphic and are extremely difficult to identify (Kollmann 1984). To solve the systematic problems of these polymorphic groups further cytological, anatomical and palynological studies are urgently needed. Cytological and palynological studies on Allium have been carried out by Radulescu (1973), Özhatay (1977), Schulze (1980) and Güler and Pehlivan (2006). However, pollen morphology and aperture evolution of the family Liliaceae have been examined by many authors (Walker 1974a, b, 1976, Harley and Zavada 2000, Pehlivan and Özler 2003, Özler and Pehlivan 2007). Some authors investigated the phylogeny of Allium using PCR-RFLP (Dubouzet and Shinoda 1998, He et al. 2000, Gurushidze et al. 2008).

In the present study, pollen morphology of 16 taxa of the genus Allium were examined.

\section{Materials and Methods}

The pollen grains were obtained from the Faculty of Pharmacy of Ankara University (AEF) and the Faculty of Arts and Science, Gazi University (GAZI) herbarium (Table 1). For morphological analysis, pollen grains were prepared according to the methods of Wodehouse (1935) and Erdtman (1960) and observations were made with Kyowa microlux-11 microscope under 1000x magnification. The measurement was based on 30 - 40 counts from each specimen. LM photographs were taken by a Zeiss microscope. For SEM investigations, pollen grains were put on stubs, sputter-coated with gold plate, and examined under a Jeol JSM-840A (Turkish Petroleum Corporation, TPAO, Turkey). For TEM studies, acetolyzed pollen grains were stained with $2 \% \mathrm{OsO}_{4}$ and uranyl acetate, dehydrated and embedded in epon araldite according to the method described by Skvarla and Turner (1966). Ultrathin sections of pollen grains were

*E-mail: hulyaozler@hotmail.com ${ }^{1}$ Department of Biology, Faculty of Arts and Science, Gazi University, Ankara-06500, Turkey. 
obtained with a glass knife in a Reichert Supernova microtome (Gazi University, Faculty of Medicine, Ankara, Turkey). Post-staining was performed with lead citrate for 5 min (Reynold 1963) and sections were examined under a Zeiss EM9 (Ankara University Research Center, Ankara, Turkey). Pollen morphological terminology of Walker (1974a), Faegri et al. (1989) and Punt et al. (1994) was followed.

Table 1. List of voucher specimens belonging to the genus Allium.

\begin{tabular}{|c|c|c|}
\hline Taxa & Localities and date of collections & $\begin{array}{l}\text { Collectors and herbaria } \\
\text { numbers }\end{array}$ \\
\hline \multicolumn{3}{|l|}{ Section Rhizirideum G. Don ex W. Koch } \\
\hline $\begin{array}{l}\text { A. albidum Fischer ex Bieb. subsp. } \\
\text { caucasicum Regel (Stearn) }\end{array}$ & $\begin{array}{l}\text { A9 Kars, Göle, above Karlıyazı village, plateau, } \\
\text { rocky places ca } 2200 \mathrm{~m}, 22.07 .90\end{array}$ & M Koyuncu 15230, AEF \\
\hline A. hymenorrhizum Ledeb. & $\begin{array}{l}\text { A9 Ardahan, Göle-Karliyazı village, Ahmet } \\
\text { meadow, arid areas, ca } 850-2000 \mathrm{~m}, 28.08 .97\end{array}$ & N Demirkuş 6000, GAZI \\
\hline \multicolumn{3}{|l|}{ Section Codonoprasum Reichb. } \\
\hline A. kunthianum Vved. & B2 Kütahya, around radar ca 1750 m, 18.08 .92 & KHC Başer 17140, AEF \\
\hline A. sipyleum Boiss. & $\begin{array}{l}\text { B2 Kütahya, Gediz, Murat mountain, Çakırören } \\
\text { village, between Sığırkuyruğu and Aseralan, ca } \\
1550 \mathrm{~m}, 21.07 .93\end{array}$ & Ö Seçmen 18453, AEF \\
\hline A. wiedemannianum Regel & $\begin{array}{l}\text { A4 Ankara, surrounding Çubuk I dam side } \\
\text { protected } 21.07 .76\end{array}$ & S Başaran 5373, AEF \\
\hline A. rupicola Boiss. ex Moulerde & $\begin{array}{l}\text { C4 İçel, Anamur, above Anamur hills, forest } \\
\text { openings, ca } 200 \mathrm{~m}, 28.05 .93\end{array}$ & M Koyuncu 18065, AEF \\
\hline \multicolumn{3}{|l|}{ Section Allium L. } \\
\hline A. trachycoleum Wendelbo & $\begin{array}{l}\text { C10 Hakkari, Yüksekova, Veregöz road, ca } 2 \\
150 \text { m, 01.07.83 }\end{array}$ & M Koyuncu 12432, AEF \\
\hline A. asperiflorum Miscz. & B6 Sivas, between Divriği and Cürek, 03.06.83 & $\begin{array}{l}\text { H Başer, H Öğütveren, } \\
\text { H Malyer 3320, AEF }\end{array}$ \\
\hline A. calyptratum Boiss. & $\begin{array}{l}\text { C5 İçel, Mersin, Arslanköy, gardens, ca } 1400 \text { m, } \\
28.07 .83\end{array}$ & M Koyuncu 17699, AEF \\
\hline A. curtum Boiss. \& Gaill. & $\begin{array}{l}\text { C4 İçel, Silifke, Silifke castle, ca } 200 \mathrm{~m} \text {, } \\
27.06 .92\end{array}$ & M Koyuncu 17380, AEF \\
\hline A. artvinense Miscz. & $\begin{array}{l}\text { A8 Bayburt, Çoruh valley, between Çakırbağ } \\
\text { (Abusta) and Darıca (Tanzut), ca } 1550 \text { m, } \\
26.07 .91\end{array}$ & M Koyuncu 17867, AEF \\
\hline A. affine Ledeb. & $\begin{array}{l}\text { A8 Erzurum, İspir, Çamlıkaya, Yavuzlar } \\
\text { neighbourhood, Quercus shrub, ca } 1640 \mathrm{~m} \text {, } \\
28.07 .91\end{array}$ & M Koyuncu 17886, AEF \\
\hline A. aucheri Boiss. & $\begin{array}{l}\text { A9 Kars, Sarıkamış, Yağbasan plateau, } \\
\text { meadows, } 2 \text { 100-2 } 400 \mathrm{~m}, 21.07 .90\end{array}$ & M Koyuncu 15232, AEF \\
\hline A. jubatum Macbride & $\begin{array}{l}\text { A4 Çankırı, between Çerkeş, İsmetpaşa, rocky } \\
\text { places, ca } 1000 \mathrm{~m}, 12.07 .92\end{array}$ & M Koyuncu 17489, AEF \\
\hline A. dictyoprasum C.A. Meyer ex Kunth & $\begin{array}{l}\text { B9 Ağrı, between Eleşkirt and Horasan, } 40 \mathrm{~km} \\
\text { before Horasan, ca } 2000 \mathrm{~m}, 05.07 .83\end{array}$ & $\begin{array}{l}\text { M Koyuncu, M Coşkun } \\
12495, \text { AEF }\end{array}$ \\
\hline A. karyeteini Post & $\begin{array}{l}\text { C5 Adana, Feke-Saimbeyli Road, } 13 \text { km, ca 650- } \\
750 \mathrm{~m}, 26.07 .93\end{array}$ & M Koyuncu 17717, AEF \\
\hline
\end{tabular}

\section{Results and Discussion}

Pollen morphology of 16 taxa of Allium was investigated under LM (Figs. 1-24), SEM (Figs. 25-53) and TEM (Figs. 54-57). The common characteristics of pollen grains were monads, monosulcate, ellipsoidal, and heteropolar. However, pollen of A. wiedemannianum is paraisopolar (Figs. 8, 31). 


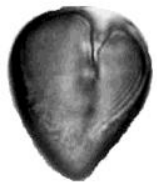

1

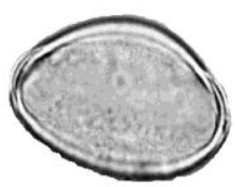

6

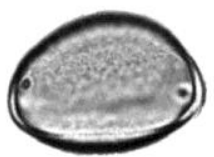

2

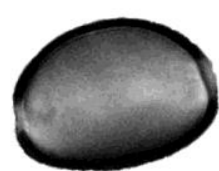

7

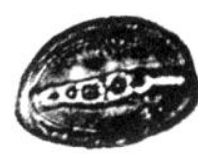

3

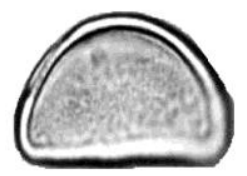

4

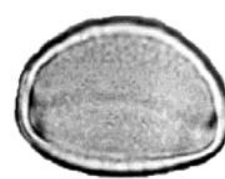

8

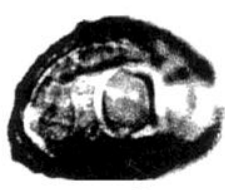

9

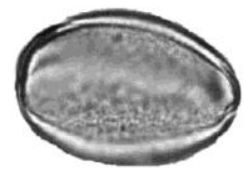

5

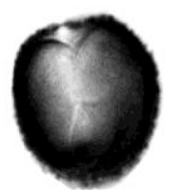

11

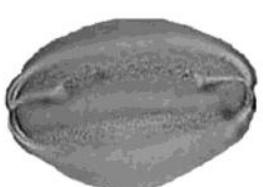

12

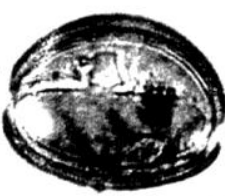

13

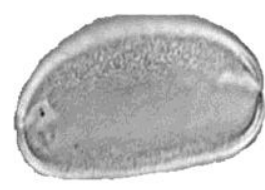

14

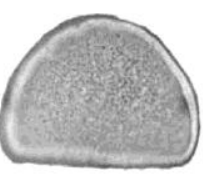

10

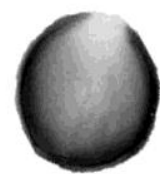

16

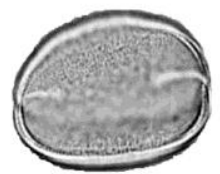

17

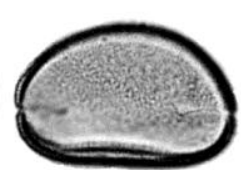

18

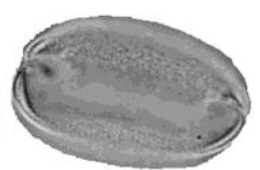

19

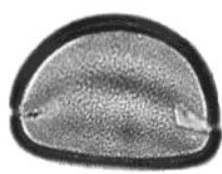

15

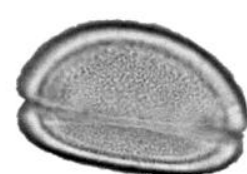

21

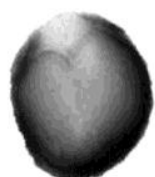

22

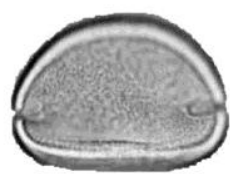

23

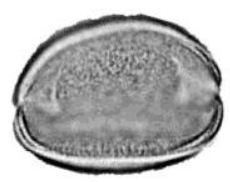

24

Figs1-24: LM photomicrographs. 1-3. A. albidum subsp. caucasicum (1. Equatorial distal view (N= non acetolysed). 2. Proximal view with ornamentation $(\mathrm{A}=$ Acetolysed). 3. Distal view with an operculum $(\mathrm{N}))$. 4-5. A. hymenorrhizum (4. Oblique view (A). 5. Proximal view and sulcus ends (A). 6. A. kunthianum, distal view, optical section (A). 7. A. sipyleum, distal view (N). 8. A. wiedemannianum, distal view with ornamentation (A). 9-10. A. rupicola (9. Distal view with an operculum $(\mathrm{N}), 10$. Oblique view (A). 11-12. A. trachycoleum (11. Equatorial distal view (N). 12. Proximal view and sulcus ends (A). 13-14. A. asperiflorum (13. distal view with an operculum (N). 14. Proximal view and sulcus ends (A). 15. A. calyptratum, proximal view with rugulate-perforate ornamentation and sulcus ends (A). 16-17. A. curtum (16. equatorial distal view (N), 17. Proximal view and sulcus ends (A). 18. A. artvinense proximal view and sulcus ends (A). 19. A. affine, proximal view and sulcus ends (A). 20. A. aucheri, oblique view with rugulate-perforate ornamentation (A). 21. A. jubatum, distal view with ornamentation, in optical section (A). 22-23. A. dictyoprasum (22. Equatorial distal view (N). 23. Proximal view and sulcus ends (A). 24. A. karyeteini, proximal view and sulcus ends (A). Bar: $10 \mu \mathrm{m}$.

The predominance of a monosulcate aperture (extended sulcate) in monocotyledons including Allium, is emphasized by Harley and Zavada (2000). Liliaceae and the overwhelming majority of the lilialean complex have monosulcate pollen grains. The evolution of distal sulcate pollen may have occurred during the Mezosoic geological period. 

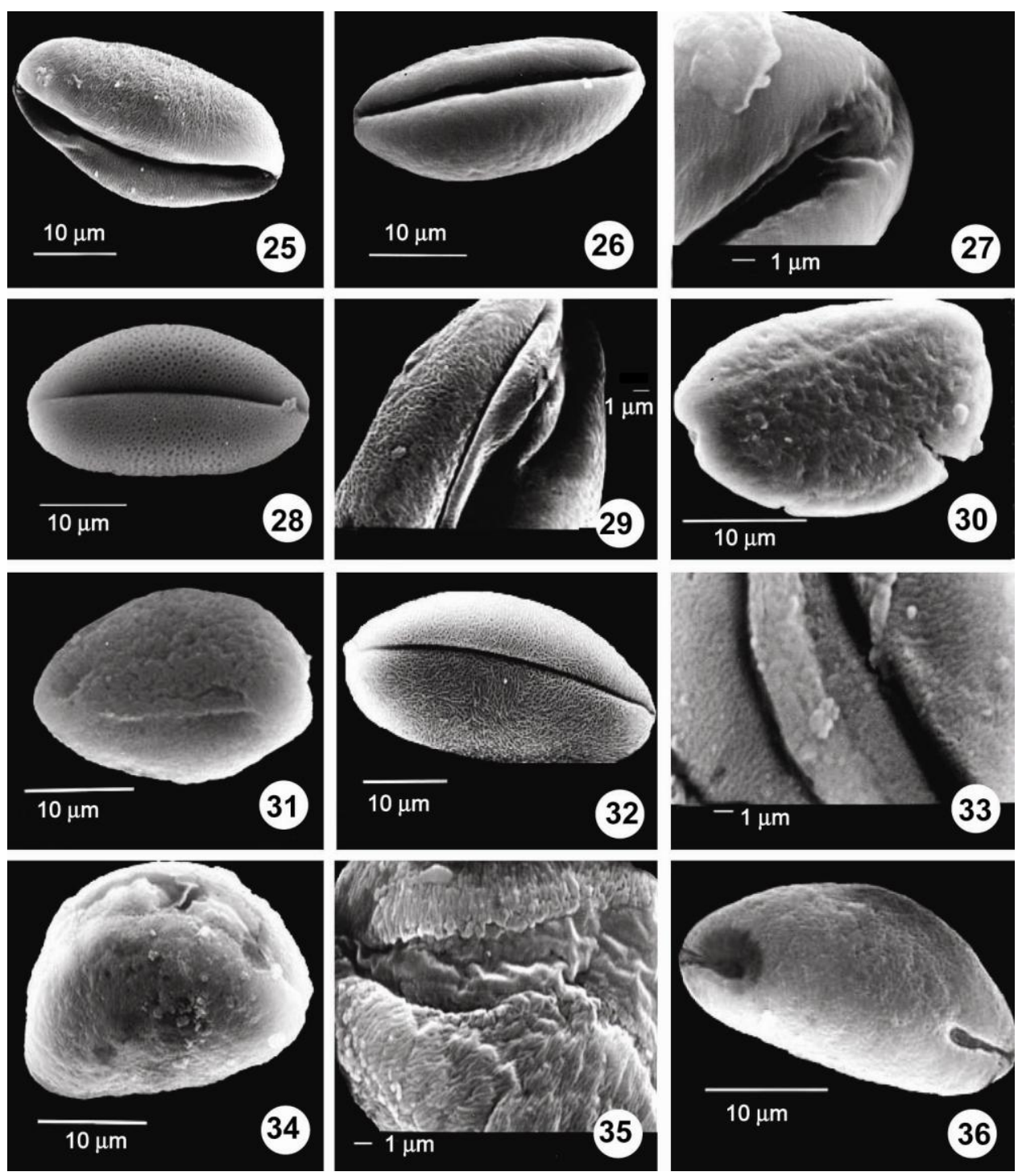

Figs 25-36: SEM photomicrographs. 25. A. albidum subsp. caucasicum, distal view with striate-perforate ornamen-tation. 26-27. A. hymenorrhizum (26. Distal view, 27. Psilate ornamentation on the sulcus membrane). 28-29. A. kunthianum (28. Distal view, 29. Striate-perforate ornamentation on the sulcus membrane). 30. A. sipyleum, distal view. 31. A. wiedemannianum, equatorial view with striate-rugulate-perforate ornamentation. 32-33. A. rupicola (32. Distal view, 33. Operculum covering the sulcus membrane). 34-35. A. trachycoleum (34. Distal view, 35. Rugulate ornamentation on the sulcus membrane). 36. A. asperiflorum, proximal view and sulcus ends.

A monosulcate aperture may be a strong palynological evidence for the common origin of monocotyledons and dicotyledons. Sulcate, colpate and colporate pollen apertures are the most common in biotically pollinated families and sulcate pollen has a much older pollen record than both porate and colpate pollen (Kuprianova 1969, 1979; Sporne 1972, Zavada 1983, Linder 2000). 

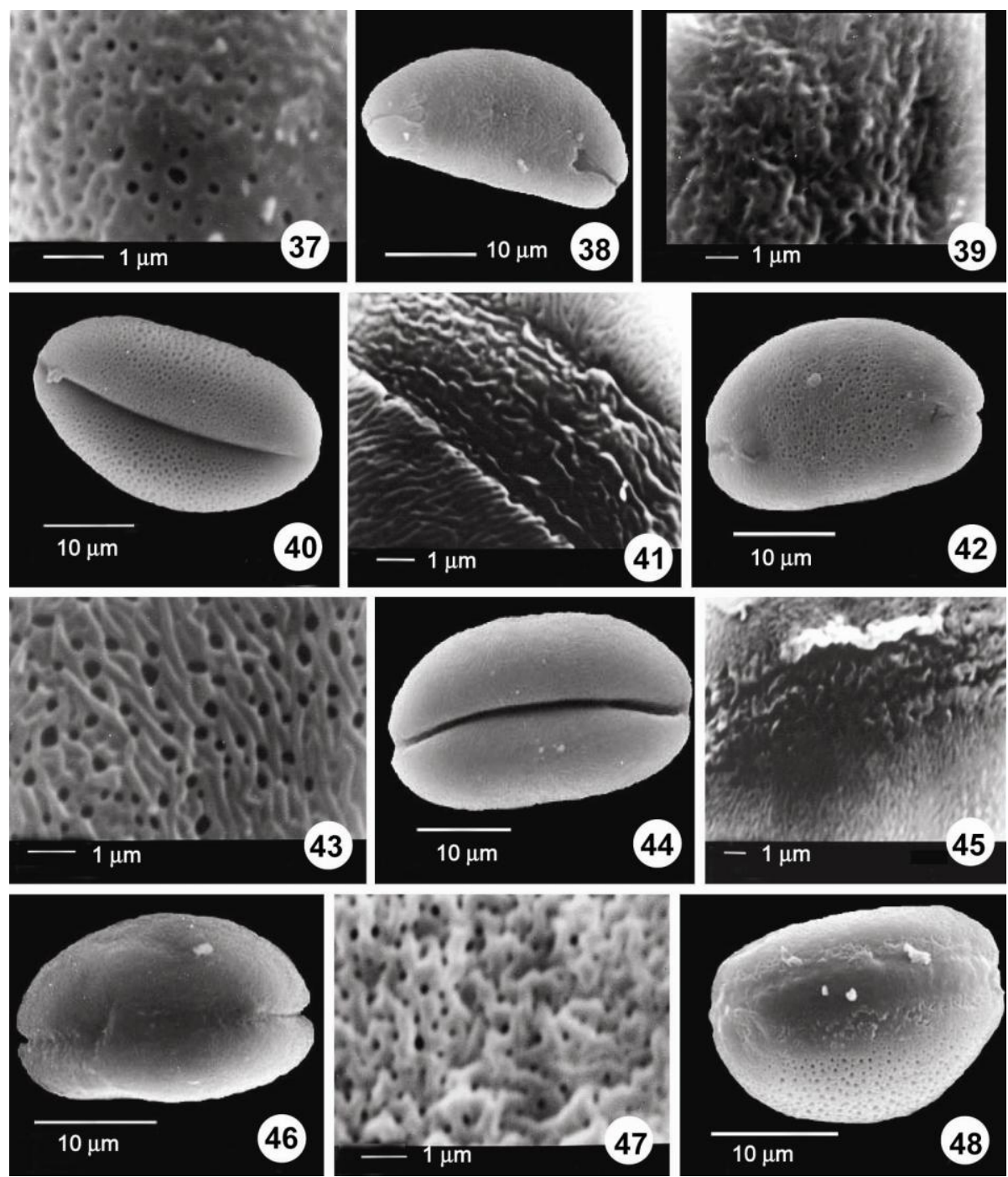

Figs 37-48: SEM photomicrographs. 37. A. asperiflorum, rugulate-perforate ornamentation. 38-39. A. calyptratum, proximal view and sulcus ends. 39. Rugulate-perforate ornamentation. 40-41. A. curtum (40. Distal view, 41. Striateperforate ornamentation). 42. A. artvinense, distal view and sulcus ends. 43. A. artvinense, striate-perforate ornamentation. 44-45. A. affine (44. Distal view. 45. Rugulate ornamentation on the sulcus membrane). 46-47. A. aucheri (46. Distal view and sulcus ends. 47. Rugulate-perforate ornamentation). 48. A. jubatum, distal view).

Biggest pollen size was found in A. calyptratum, whereas the smallest was found in $A$. karyeteini (Table 2). The pollen size given for this genus are $19.3 \mu \mathrm{m} \times 55.2 \mu \mathrm{m}$ (Radulescu 1973), $25.75 \mu \mathrm{m} \times 17.48 \mu \mathrm{m}-51.19 \mu \mathrm{m} \times 32.30 \mu \mathrm{m}$ (Özhatay 1977), $25.50 \mu \mathrm{m} \times 18.44 \mu \mathrm{m}-44.52 \times$ $26.80 \mu \mathrm{m}$ (Güler and Pehlivan 2006). It is reasonably accepted that pollen grain size is positively correlated with chromosome number. However, in the present study it was observed that some taxa with bigger pollen grains have lower chromosome numbers (e.g. A. kunthianum and A. asperiflorum where, $2 \mathrm{n}=16$ ) and some taxa with bigger pollen size have higher chromosome number (e.g. A. trachycoleum, $2 \mathrm{n}=32,48$ ). 

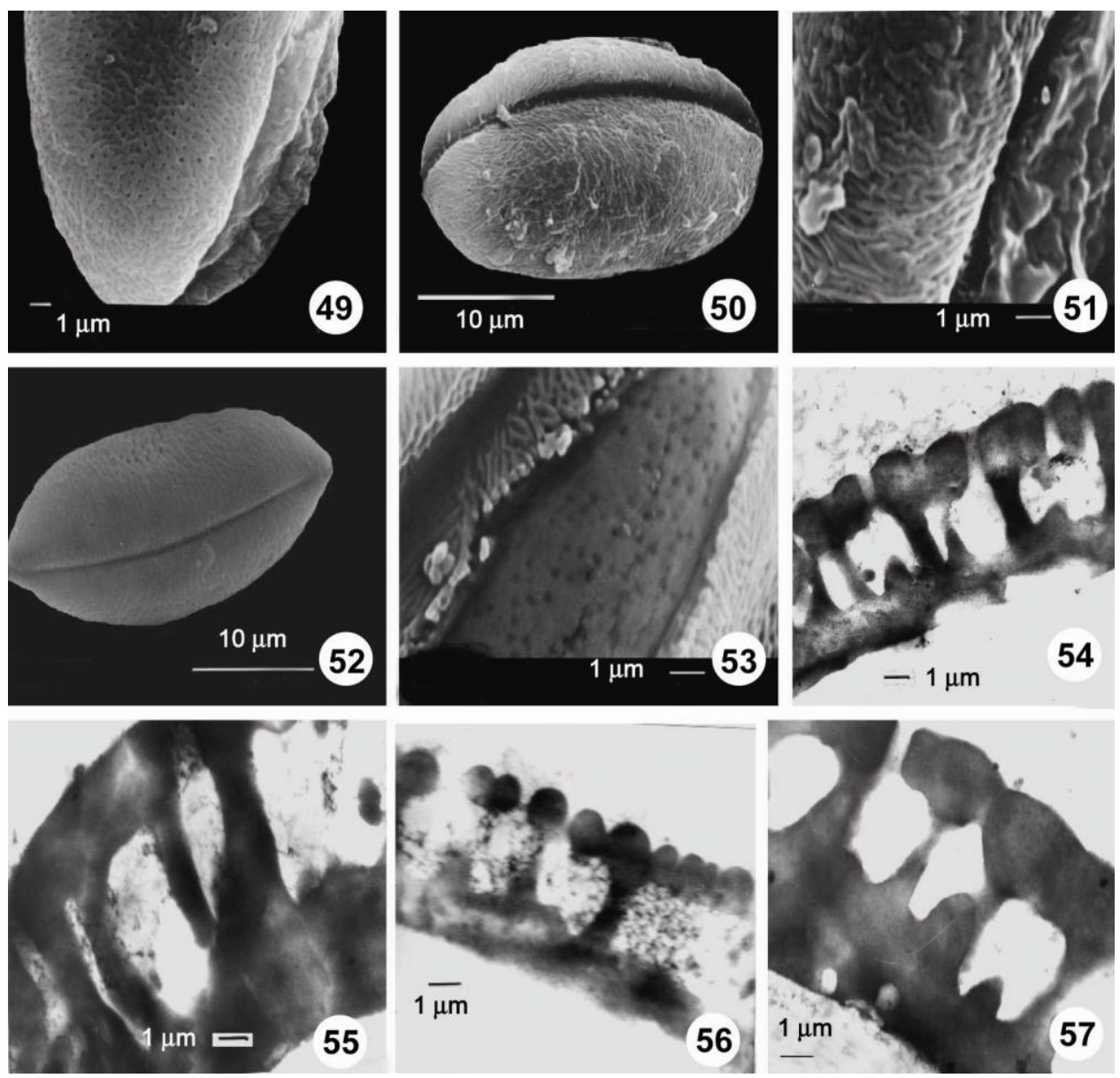

Figs 49-53: SEM photomicrographs. 49. A. jubatum (49. Rugulate-perforate ornamentation). 50-51. A. dictyoprasum (50. Distal view, 51. Striate-rugulate-perforate ornamentation on the sulcus membrane). 52-53. A. karyeteini (52. Distal view, 53. Perforate ornamentation on sulcus membrane).

Figs 54-57: TEM photomicrographs of exine structure (54. A. albidum subsp. caucasicum. 55. A. trachycoleum. 56. A. curtum. 57. A. jubatum).

It was recognized that the sulcus extends from distal to proximal end in all the taxa investigated. The proximal extension of the sulcus ranged from $7.07-15.79(\mathrm{~N})$ to $7.73-18.12(\mathrm{~A})$ $\mu \mathrm{m}$ (Table 2). The extended sulcus type has been observed on Allium and the family Liliaceae (Güler and Pehlivan 2006, Özler and Pehlivan 2007). Chanda et al. (1979) explained that an extended sulcate-type of aperture was not common but, it was found occasionally in both dicotyledons and monocotyledons. The sulcus ends were sharp in A. albidum subsp. caucasicum, A. kunthianum, A. sipyleum, A. wiedemannianum, and A. rupicola, whereas the sulcus ends were truncate in A. affine. The sulcus ends were rounded in the other investigated taxa (Figs 1-24, 36, $38,42,46)$. The longest sulcus extension dimension was measured in A. calyptratum, whereas the shortest dimension was observed in A. hymenorrhizum. The widest sulcus dimension was seen in A. wiedemannianum. The longest length dimension of sulcus was seen in A. calyptratum and the shortest dimension was seen in A. albidum subsp. caucasicum (Table 2). Several researchers have emphasized that the sulcus features and the presence of operculum may be a taxonomic value in 
some families (Schulze 1980, 1982, Kosenko 1991a, 1991b, 1999, Halbritter and Hesse 1993, Friis et al. 1997, Güler and Pehlivan 2006). In SEM photomicrographs, sulcus membranes are psilate in A. hymenorrhizum, A. sipyleum, A. wiedemannianum, A. artvinense, A. aucheri, and $A$. jubatum. Striate - reticulate sulcus membrane ornamentation was seen in A. albidum subsp. caucasicum, A. kunthianum, and $A$. rupicola. Rugulate sulcus membrane ornamentation was found in A. trachycoleum, A. asperiflorum, A. calyptratum, A. curtum, A. affine and A. dictyoprasum. A perforate sulcus membrane was found in A. karyeteini (Figs 25-53). Similarly, Güler and Pehlivan (2006) reported that sulcus membrane ornamentatios were psilate, psilate-perforate and rugulateperforate in Allium taxa. An operculum was seen in A. albidum subsp. caucasicum (Section Rhizirideum), A. rupicola (Section Codonoprasum), and A. asperiflorum (Section Allium). The operculum was found to be fragmented on the sulcus membrane (Figs 3, 9, 13) or sometimes completely covering it (Figs 3, 9, 13, 33). In the other similar study of this genus, the operculum was determined only in A. pallens subsp. pallens, A. bassitense and A. hirtovaginum under the Section Codonoprasum (Güler and Pehlivan 2006). According to Kosenko (1991a, 1991b, 1992), a non-operculate exine is a plesiomorphic peculiarity. In the present investigation, A. albidum subsp. caucasicum, A.rupicola, and A.asperiflorum, which posses an operculum are more advanced than other taxa examined.

In the present investigated taxa (such as A. albidum subsp. caucasicum, A. curtum, A. trachycoleum, and $A$. jubatum), the exine was semitectate and the tectum with perforate. Perforate pollen wall in the monocotyledons is a plesiomorphic character and the endexine is rarely seen in the monocotyledones (Zavada 1983, 1984). Palaeopalynological studies have shown that, in early period of angiosperm evolution, a tectate-perforate and semitectate exine is seen predominantly (Walker 1974a, b, Crane 1989, Hughes and Audrey 1994). Although the endexine was very thin with interruptions in A. trachycoleum and A. curtum, it was very thin without interruptions in $A$. albidum subsp. caucasicum and A. jubatum (Figs 54-57). The thickest exine dimension was found in A. jubatum and the thinnest exine dimension was found in A. hymenorrhizum (Table 2). In the present survey, the number of perforations in $1 \mu \mathrm{m}^{2}$ was between 3 and 11 at the sulcus side or at the lateral surface. The diameter of a perforation was approximately $0.08-0.75 \mu \mathrm{m}$. The diameter of perforation was observed to be the highest in A. asperiflorum (Fig. 37). The number of perforations in $1 \mu \mathrm{m}^{2}$ was more in A. albidum subsp. caucasicum (Fig. 25).

According to SEM survey, the exine sculpture was striate-perforate, striate-rugulateperforate and rugulate-perforate (Table 2, Figs 25-53). However, in A. wiedemannianum, one of the lateral surfaces of the pollens is striate-rugulate-perforate and the other surface of the pollen grains was striate-perforate (Fig. 31). Therefore, this pollen grain is para-isopolar. Perforatestriate, perforate-rugulate and perforate-striate-rugulate exine structure have been reported in previous investigations (He et al. 2000, Güler and Pehlivan 2006). Radulescu (1973) described that the tribe Allieae pollen had reticulate mostly microreticulate exine sculpturing and grouped Allieae pollen grains according to the density of the microreticulum.

The present study revealed that Allium taxa possess three types ornamentational characteristics as follows:

(i) Striate - perforate: A. albidum subsp. caucasicum, A. kunthianum, A. rupicola, A. curtum, A. artvinense, $A$. affine and $A$. karyeteini.

(ii) Striate - rugulate-perforate: A. hymenorrhizum, A. sipyleum, A. wiedeman-nianum, A. dictyoprasum and A. trachycoleum.

(iii) Rugulate - perforate: A. asperiflorum, A. calyptratum, A. aucheri and A. jubatum.

The A. sipyleum and A. karyeteini had thickest intine while A. hymenorrhizum had thinnest one (Table 2). 


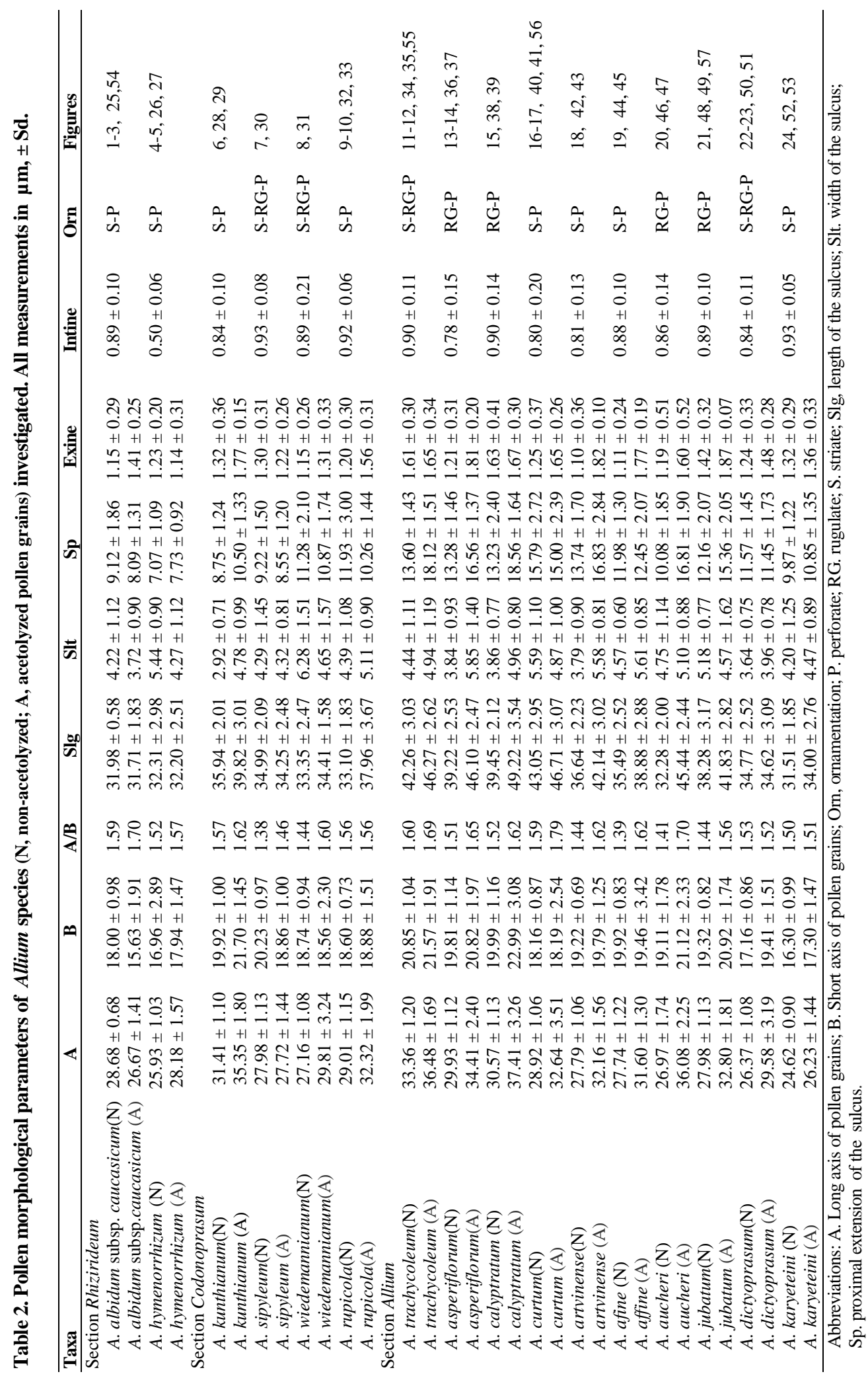


Section Rhizirideum has been proved as non monophyletic based on moleculer results. There is close genetic relationship between subgenera Allium and Rhizirideum. (Dubouzet and Shinoda 1998, He et al. 2000). The results revealed that further molecular and morphological studies are needed to solve the problems related to taxonomy of this genus.

\section{Acknowledgements}

The authors thank collectors, especially Professor Mehmet Koyuncu from the Faculty of Pharmacy of Ankara University, for allowing to use their specimens.

\section{References}

Chanda S, K. Gosh and S. Nillson. 1979. On the polarity and tetrad arrangement in some mono and diaperturate angiosperm pollen grains. Grana 18: 21-31.

Crane P.R. 1989. Paleobotanical evidence on the early radiation of nonmagnoliid dicotyledones. Plant Sys. Evol. 162: 165-191.

Davis P.H., R.R. Mill and K. Tan. 1984. Flora of Turkey and the East Eagean Islands. Edinburgh Univ. Press, Edinburgh.

Davis P.H., R.R. Mill and K. Tan. 1988. Flora of Turkey and the East Eagean Islands (Supplement). Edinburgh Univ. Press, Edinburgh.

Dubouzet J.G. and K. Shinoda. 1998. Phylogeny of Allium L. subgen. Melanocrommyum (Webb et Berth.) Rouy based on DNA sequence analysis of the internal transcribed spacer region of nrDNA. Theor. Appl. Genet. 97: 541-549.

Erdtman G. 1960. The acetolysis method: A revised description. Sven. Bot. Tidskr. 54: 561-564.

Faegri K, P.E. Kallland and K.J. Knzywinski (Eds). 1989. Textbook of pollen analysis. Wiley \& Sons, New York.

Friis E.M., P.R. Crane and K.R. Pedersen. 1997. Anacostia, a new basal angiosperm from the early Cretaceous of North America and Portugal with trichotomocolpate/monocolpate pollen. Grana 36: 225-244.

Gurushidze M., R.M. Fritsch and F.R. Blattner. 2008. Phylogenetic analysis of Allium sung. Melanocrommyum infers cryptic species and demands a new sectional classification. Science directMoleculer phylogenetics and evolution (www.sciencedirect.com/science).

Güler Ü. and S. Pehlivan. 2006. Pollen morphology of some species belonging to Codonoprasum and Allium sections of Allium (Liliaceae-Alliaceae) genus. Biologia Bratislava 61: 449-455.

Güner A., N. Özhatay, T. Ekim and K.H. Canbaşer. 2000. Flora of Turkey and the East Eagean Islands (Supplement. 2). Edinburgh Univ. Press, Edinburgh.

Halbritter, H. and M. Hesse. 1993. Sulcus morphology in some monocot families. Grana 32: 87-99.

Harley M.M. and M.S. Zavada. 2000. Pollen of the monocotyledons: Selecting characters for cladistic analysis. In: Monocots: Systematics and Evolution, K.L. Wilson and D.A Morrison (Eds), pp. 194-213. CSIRO, Melbourne.

He X., S. Ge, J. Xu and D. Hong. 2000. Phylogeny of Chinese Allium (Liliaceae) using PCR-RFLP analysis. Science in China (Series C) 43(5): 454-463.

Hughes N.F. and B. Audrey. 1994. Search for antecedents of early creataceous monosulcate columellate pollen. Rev. Palaeobot. Palynol. 83: 175-183.

Kollmann F. 1984. Allium L. In: Flora of Turkey and the East Eagean Islands, P.H. Davis, R.R. Mill and K.Tan (Eds), p. 99. Edinburgh Univ. Press, Edinburgh.

Kosenko V.N. 1991a. Pollen morphology of the genus Fritillaria (Liliaceae). Bot. Zh. 76: 1696-1706.

Kosenko V.N. 1991b. Pollen morphology of the family Liliaceae s. str. Bot. Zh. 76: 1201-1210.

Kosenko V.N. 1992. Pollen morphology and systematic problems of the Liliaceae family. Bot. Zh. 77: 1-15. 
Kosenko V.N. 1999. Contributions to the pollen morphology and taxonomy of the Liliaceae. Grana 38: 20-30.

Kuprianova L.A. 1969. On the evolutionary levels in the morphology of the pollen grains and spores. Pollen et Spores 11: 333-351.

Kuprianova L.A. 1979. On the possibility of the development of tricolpate pollen from monosulcate. Grana. 18: $1-4$.

Linder H.P. 2000. Pollen morphology and wind pollination in angiosperms. In: Pollen and Spores: Morphology and Biology, M.M. Harley, C.M. Morton and S. Blackmore (Eds). pp. 73-88. Royal Botanic Gardens, Kew.

Özhatay N. 1977. Trakya bölgesi ve İstanbul çevresi Alliaceae familyası üzerinde taksonomik, sitolojik ve palinolojik araştırmalar. İ.Ü. Eczacılık Fakültesi Farmasötik Botanik kürsüsü, Doçentlik Tezi.

Özler H. and S. Pehlivan. 2007. Comparison of pollen morphological structures of some taxa belonging to Asparagus L. and Fritillaria L. (Liliaceae) from Turkey. Bangladesh J.Bot. 36(2): 111-120.

Pehlivan S. and H. Özler. 2003. Pollen morphology of some species of Muscari Miller (LiliaceaeHyacinthaceae) from Turkey. Flora 198: 200-210.

Punt W.S. Blackmore, S. Nilsson and A. Le Thomas. 1994. Glossary of Pollen and Spore Terminology. LPP Foundation, Uttecht.

Radulescu D. 1973. Recherches morpho-palynologiques sur la famille Liliaceae. Acta Bot. Horti. Bucur. 133248.

Reynold E.S. 1963. The use of lead citrate at high pH as an electron opaque stain in electron microscopy. Stain. Tech. 43: 139-144.

Schulze W. 1980. Beiträge zur taxonomie der Liliifloren VI. Der umfang der Liliaceae. Math. Nat. 29: 607-636.

Schulze W. 1982. Beiträge zur taxonomie der Liliifloren $\times$ Asparagaceae. Math. Nat. 31: 309-330.

Seçmen Ö., Y. Gemici, G. Görk, L. Bekât and E. Leblebici. 1998. Tohumlu bitkiler sistematiği. Ege Üniversitesi Basımevi, Bornova, İzmir. s. 396.

Skvarla J.J. and B.L. Turner. 1966. Systematic implications from electron microscopic studies of Compositae pollen. Ann. Mo. Bot. Gard. 53: 220-256.

Sporne K.N. 1972. Some observations on the evolution of pollen types in dicotyledons. New Phytol. 71:181-185.

Walker J.W. 1974a. Evolution of exine structure in the pollen of primitive angiosperms. Am. J. Bot. 61: 891902.

Walker J.W. 1974b. Aperture evolution in the pollen of primitive angiosperms. Am. J. Bot. 61: 1112-1136.

Walker J.W. 1976. Evolutionary significance of the exine in the pollen of primitive angiosperms. In: The Evolutionary Significance of the Exine, I.K. Ferguson and J. Muller (Eds). pp. 251-308. Linnean Soc. Symp. Series 1. Academic Press, London.

Wodehouse R.P. 1935. Pollen grains. MacGraw Hill, New York. 574 pp.

Zavada M.S. 1983. Comparative morphology of monocot pollen and evolutionary trends of apertures and wall structures. Bot. Rev. 49: 331-378.

Zavada M.S. 1984. Angiosperm origins and evolution based on dispersed fossil pollen ultrastructure. Ann. Miss. Bot. Gard. 71: 444-463.

(Manuscript received on 27 May 2009; revised on 12 September 2009) 